\title{
Influence of the cis/trans configuration on the supramolecular aggregation of aryltriazoles
}

\author{
Sara Tejera, Giada Caniglia, Rosa L. Dorta, Andrea Favero, Javier González-Platas \\ and Jesús T. Vázquez ${ }^{*}$
}

\author{
Full Research Paper \\ Address: \\ Instituto Universitario de Bio-Orgánica "Antonio González", \\ Departamento de Química Orgánica, Universidad de La Laguna, \\ 38206 La Laguna, Tenerife, Spain \\ Email: \\ Jesús T. Vázquez* - jtruvaz@ull.edu.es \\ * Corresponding author \\ Keywords: \\ circular dichroism; cis/trans configuration; gels; triazole; X-ray \\ diffraction
}

Beilstein J. Org. Chem. 2019, 15, 2881-2888.

doi:10.3762/bjoc. 15.282

Received: 29 July 2019

Accepted: 08 November 2019

Published: 28 November 2019

Associate Editor: H. Ritter

(C) 2019 Tejera et al.; licensee Beilstein-Institut.

License and terms: see end of document.

\begin{abstract}
The ability of trans- and cis-1,2-glucopyranosyl and cyclohexyl ditriazoles, synthesized by CuAAC "click" chemistry, to form gels was studied, their physical properties determined, and the self-aggregation behavior investigated by SEM, X-ray, and EDC studies. The results revealed that self-assembly was driven mainly by $\pi-\pi$ stacking interactions, in addition to hydrogen bonding, with the aromatic rings adopting a high degree of parallelism, as seen in crystal packings and ECD data. Furthermore, $\pi$-bromine interactions between the bromine atom of the aryl substituents and the triazole units might also contribute to an overall stabilization of the supramolecular aggregation of bis(4-bromophenyl)triazoles. The trans or cis spatial disposition of the triazole rings is highly important for gelation, with the cis configuration having higher propensity.
\end{abstract}

\section{Introduction}

Structures self-assembled by noncovalent interactions give rise to supramolecular architectures with specific physical and/or chemical properties. Gels are colloid systems in which the dispersed phase has combined with the dispersion medium to yield a semisolid material. Gels from low-molecular-weight gelators have potential applications in high-tech materials [1-3] and biomedical sciences [3-6]. Triazole derivatives have shown excellent gelation properties [7-10], in addition to a broad range of biological activities [11-14].
During the synthesis and characterization process of glucosyl mono- and ditriazole derivatives, which we carried out in order to analyze the use of aryltriazoles for the determination of absolute configuration [15], we serendipitously discovered that these glucosyl ditriazoles led to gels. Therefore, we carried out the corresponding supramolecular studies and report herein the ability of ditriazoles to form gels, their physical properties, as well as the dependence of these properties on the cis/trans relative configuration. 


\section{Results and Discussion}

A large set of mono- and ditriazoles was synthesized using cycloaddition reactions based on "click" chemistry [16-18] of azides and alkynes catalyzed by $\mathrm{Cu}(\mathrm{I})$ salts, the $\mathrm{CuAAC}$ reaction. Self-assembling properties were not observed for any of the prepared monotriazoles, namely the 4-substituted 1-glucopyranosyltriazoles $\mathbf{1 a - g}$ and $\mathbf{2 a - g}$ (Scheme 1) [15]. However, most ditriazoles $\mathbf{7 a - g}$ and $\mathbf{8 a}-\mathbf{g}$ (Scheme 2) showed supramolecular features, i.e., their DMSO solutions prepared for NMR analyses spontaneously transformed into gels inside the NMR tubes.

Three cis-/trans-configured pairs of compounds were chosen for a gelation ability study. Thus, analogue pairs $8 f / 7 f$ (Scheme 2), 10/9 (Scheme 3), and 14/12 (Scheme 4) were selected. The pair $\mathbf{8 f} / \mathbf{7 f}$ was chosen for having different anomeric configurations in the glucosyl system, and therefore different cis/trans relationships with the equatorial substituent<smiles></smiles>

$\mathrm{R}=$<smiles>[R]CCCCCCC(=O)OCCCO</smiles><smiles>Cc1ccc(O)cc1</smiles><smiles>Cc1ccc(Br)cc1</smiles>

Scheme 1: Structures of 4-substituted 1-glucopyranosyltriazoles 1a-g and $\mathbf{2 a - g}$ [15]. in position 2. Compounds $\mathbf{9}$ and $\mathbf{1 0}$ were selected to monitor the effects of the unprotected hydroxy groups, and the last pair, 14/12, for being a non-glycosyl system, yet with the same cis/trans relationship as the former compounds. In addition, the available compounds $\mathbf{8 a}, \mathbf{8 b}$, and $\mathbf{8 e}$ (cis) [15] were also tested for gelation to support the results.

Compounds 7 and 8 (Scheme 2) were successfully prepared from the corresponding alkynes and diazides $\mathbf{5}$ and $\mathbf{6}$, respectively. In this context, it was required to isolate $\mathbf{5}$ and $\mathbf{6}$ before the coupling reaction could be performed.

Compounds 9 and 10 (Scheme 3) were obtained in good yields by treatment of $\mathbf{7 f}$ and $\mathbf{8 f}$, respectively, with sodium methoxide in $\mathrm{CH}_{2} \mathrm{Cl}_{2} / \mathrm{MeOH}$.

The trans- and cis-1,2-di(triazol-1-yl)cyclohexanes 12 [14] and 14 (Scheme 4), respectively, were prepared from 1-bromo-4-<smiles>OCC1OC(n2cc(-c3ccc(Br)cc3)nn2)[C@H](n2cc(-c3ccc(Br)cc3)nn2)[C@H](O)[C@@H]1O</smiles><smiles>OCC1O[C@@H](n2cc(-c3ccc(Br)cc3)nn2)[C@@H](n2cc(-c3ccc(Br)cc3)nn2)[C@H](O)[C@@H]1O</smiles>

Scheme 3: Compounds 9 (trans) and 10 (cis) [15].<smiles>N[C@@H]1OC(CO)[C@H](O)[C@@H](O)C1O</smiles>

3<smiles>CC(=O)OCC1O[C@H](OC(C)=O)C(N)[C@H](OC(C)=O)[C@H]1OC(C)=O</smiles>

$4(98 \%, \alpha / \beta, 1: 5)$<smiles>[AsH3][AsH3]</smiles>

$6 \underset{2 \rightleftharpoons \mathrm{CuAAC}}{\stackrel{\mathrm{R}}{\rightleftharpoons}}$<smiles>CC(=O)OCC1OC(N)C(N)[C@H](OC(C)=O)[C@H]1OC(C)=O</smiles>

5

$(68 \%, \beta / \alpha, 1: 3)$<smiles>CC(=O)OCC1O[C@H](N)C(N)[C@H](OC(C)=O)[C@H]1OC(C)=O</smiles>

6

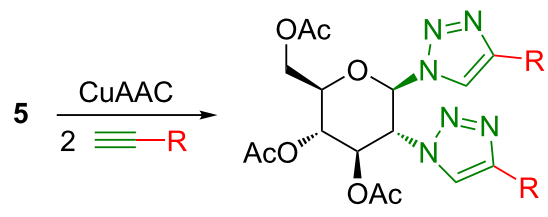

$7 a-g(65-95 \%)$

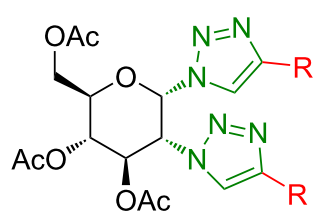

8a-g (55-95\%) 

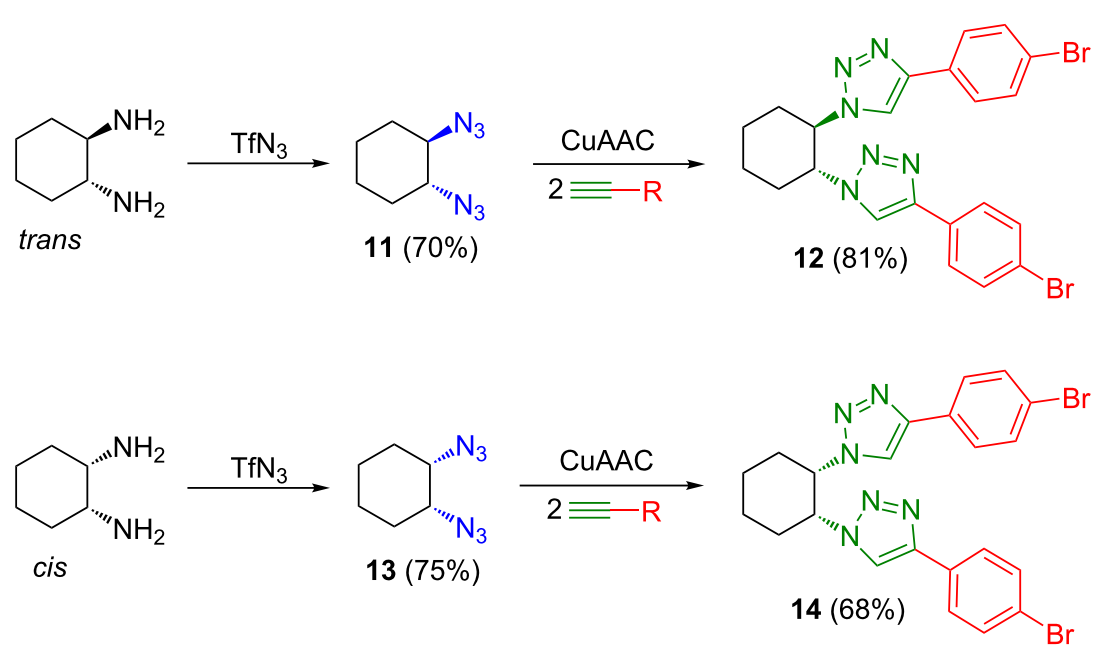

Scheme 4: Synthesis of $(1 R, 2 R)$ - and (1R,2S)-1,2-bis-(4-(4-bromophenyl)-1H-triazol-1-yl)cyclohexane (12 and 14).

ethynylbenzene and their corresponding diazides, $\mathbf{1 1}$ and $\mathbf{1 3}$, through CuAAC reactions [16-18].

As can be seen in Figure 1 and Table 1, all these compounds except 9 (having a trans configuration) formed gels in DMSO or DMSO/ $\mathrm{H}_{2} \mathrm{O}$ mixtures. While the ditriazole species with an $\alpha$-anomeric configuration, $\mathbf{8 f}$ (cis), was able to form gels at different concentrations and $\mathrm{DMSO} / \mathrm{H}_{2} \mathrm{O}$ ratios, its $\beta$-anomer $7 \mathbf{f}$ (trans) only formed a gel when the sample was exposed to a temperature of $8{ }^{\circ} \mathrm{C}$ in a refrigerator. This temperature gave rise to an opaque gel that melted above $18^{\circ} \mathrm{C}$ (Table 2). The same approach, along with reduction of the minimum gelation concentration to $1.1 \% \mathrm{w} / \mathrm{w}$ (in DMSO) was used to obtain a gel based on $\mathbf{8 f}$. In addition, this compound proved to be an effective translucent/transparent low-molecular-weight gelator in aqueous solutions of DMSO, forming gels in DMSO/ $\mathrm{H}_{2} \mathrm{O}, 2: 1$, $\mathrm{v} / \mathrm{v}$ at a minimum concentration of $0.8 \% \mathrm{w} / \mathrm{w}$. The presence of water favored gel formation, decreased the gelation concentration, and the gel's appearance became translucent/transparent. In addition, these gels were stable for several months in sealed vials, although they could be disrupted by agitation or heating. However, the gel state could be restored through cooling.

The triol 9 (trans) did not lead to any gel, while its $\alpha$-anomer 10 (cis) produced translucent and transparent gels, respectively, in 1:1 and 1:2 ratios of DMSO/ $\mathrm{H}_{2} \mathrm{O}, \mathrm{v} / \mathrm{v}$ (Table 1 and Table 2). In addition, compound $\mathbf{1 0}$ (cis) exhibited the lowest minimum gelation concentration, $0.5 \% \mathrm{w} / \mathrm{w}$ in $\mathrm{DMSO} / \mathrm{H}_{2} \mathrm{O}(1: 2, \mathrm{v} / \mathrm{v})$

Compounds having an $\alpha$-anomeric configuration (cis), independent of the hydroxy groups, were either acetylated (8f) or not (10), forming gels much easier than their corresponding $\beta$-anomers (trans). This showed that their ability to form gels

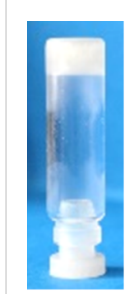

$7 f$

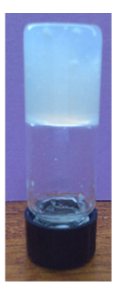

$8 f$

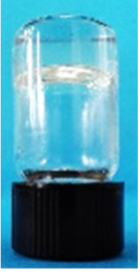

10

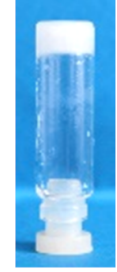

12

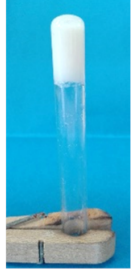

14
Figure 1: Tube inversion test: gels formed by compounds $\mathbf{7 f}, \mathbf{8 f}, \mathbf{1 0}$, 12 , and 14.

was critically dependent on the cis/trans configuration present in the molecule.

To confirm this result, the supramolecular properties of transand cis-1,2-bis(4-(4-bromophenyl)-1H-triazol-1-yl)cyclohexanes 12 and 14, having the same configuration as compounds $7 \mathbf{f}$ and 8f, respectively, were analyzed. Both compounds formed gels, but the trans stereoisomer 12 did so only at a low temperature $\left({ }^{\circ} \mathrm{C}\right)$ in DMSO $(\mathrm{G}=1.1, \mathrm{w} / \mathrm{w})$, similar to the $\beta$-anomer 7f, which possessed the same trans configuration. On the other hand, the cis stereoisomer $\mathbf{1 4}$ formed an opaque gel at room temperature in $\mathrm{DMSO} / \mathrm{H}_{2} \mathrm{O}, 9: 1, \mathrm{v} / \mathrm{v}(\mathrm{G}=0.8$, $\mathrm{w} / \mathrm{w}$ ), showing a higher potency for gelation, similar to $\mathbf{8 f}$. As such, this relationship mirrors the behavior observed for the 7f $/ \mathbf{8 f}$ pair. Table 2 also contains the different $T_{\mathrm{gs}}$ values obtained by the dropping ball method.

Supportive of these conclusions is the facility of cis-configured ditriazoles to form gels. Thus, compound $\mathbf{8 a}$, with alkyl groups in position 4 on the triazolyl groups, and compound $\mathbf{8 e}$, with tolyl groups in that position, gelled easily (Table 1 and Table 2). 


\begin{tabular}{|c|c|c|c|c|c|c|c|}
\hline$\#$ & Config & DMSO & $\begin{array}{c}\mathrm{DMSO} / \mathrm{H}_{2} \mathrm{O} \\
(9: 1, \mathrm{v} / \mathrm{v})\end{array}$ & $\begin{array}{c}\mathrm{DMSO} / \mathrm{H}_{2} \mathrm{O} \\
(3: 1, \mathrm{v} / \mathrm{v})\end{array}$ & $\begin{array}{c}\mathrm{DMSO} / \mathrm{H}_{2} \mathrm{O} \\
(2: 1, \mathrm{v} / \mathrm{v})\end{array}$ & $\begin{array}{c}\mathrm{DMSO} / \mathrm{H}_{2} \mathrm{O} \\
(1: 1, \mathrm{v} / \mathrm{v})\end{array}$ & $\begin{array}{c}\mathrm{DMSO} / \mathrm{H}_{2} \mathrm{O} \\
(1: 2, \mathrm{v} / \mathrm{v})\end{array}$ \\
\hline $7 f$ & $\beta$ (trans) & $\mathrm{G} 1.1^{\mathrm{a}}$ & - & $p$ & $p$ & $p$ & $p$ \\
\hline $8 f$ & $\alpha(c i s)$ & $\begin{array}{l}\text { G } 5.0 \\
\text { G } 1.1^{a}\end{array}$ & - & G 0.8 & G 0.8 & $p$ & $p$ \\
\hline 9 & $\beta$ (trans) & s & s & $p$ & $p$ & $p$ & $p$ \\
\hline 10 & $\alpha(c i s)$ & $\mathrm{s}$ & - & $\mathrm{s}$ & $\mathrm{s}$ & G 0.7 & G 0.5 \\
\hline 12 & trans & $\mathrm{G} 1.1^{\mathrm{a}}$ & $p$ & $p$ & $p$ & $p$ & $p$ \\
\hline 14 & cis & s & G 0.8 & $p$ & $p$ & $p$ & $p$ \\
\hline $8 a$ & cis & - & - & - & G 1.0 & susp & susp \\
\hline $8 b$ & cis & - & - & - & weak $G$ & susp & $\mathrm{p}$ \\
\hline $8 e$ & cis & - & - & - & G 1.0 & G 1.0 & susp \\
\hline
\end{tabular}

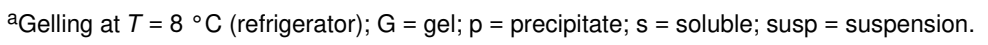

\begin{tabular}{|c|c|c|c|c|c|}
\hline$\#$ & Config & Conditions & CGC & $T_{\text {gs }}\left({ }^{\circ} \mathrm{C}\right)$ & Appearance \\
\hline $7 f$ & $\beta$ (trans) & DMSOa $^{a}$ & 1.1 & $20 \pm 2$ & opaque \\
\hline $8 f$ & $\alpha($ cis $)$ & DMSO & 5.0 & $63 \pm 1$ & translucent \\
\hline $8 f$ & $\alpha($ cis $)$ & $\mathrm{DMSO}^{\mathrm{a}}$ & 1.1 & $20 \pm 2$ & opaque \\
\hline $8 f$ & $\alpha($ cis $)$ & $\mathrm{DMSO} / \mathrm{H}_{2} \mathrm{O}(3: 1, \mathrm{v} / \mathrm{v})$ & 0.8 & $93 \pm 3$ & translucent \\
\hline $8 f$ & $\alpha($ cis $)$ & $\mathrm{DMSO} / \mathrm{H}_{2} \mathrm{O}(2: 1, \mathrm{v} / \mathrm{v})$ & 0.8 & $95 \pm 3$ & transparent \\
\hline 10 & $\alpha($ cis $)$ & $\mathrm{DMSO} / \mathrm{H}_{2} \mathrm{O}(1: 1, \mathrm{v} / \mathrm{v})$ & 0.7 & $68 \pm 1$ & translucent \\
\hline 10 & $\alpha($ cis $)$ & $\mathrm{DMSO} / \mathrm{H}_{2} \mathrm{O}(1: 2, \mathrm{v} / \mathrm{v})$ & 0.5 & $94 \pm 3$ & transparent \\
\hline 12 & trans & DMSO $^{\mathrm{a}}$ & 1.1 & $20 \pm 2$ & opaque \\
\hline 14 & cis & $\mathrm{DMSO} / \mathrm{H}_{2} \mathrm{O}(9: 1, \mathrm{v} / \mathrm{v})$ & 0.8 & $50 \pm 2^{b}$ & opaque \\
\hline $8 a$ & cis & $\mathrm{DMSO} / \mathrm{H}_{2} \mathrm{O}(2: 1, \mathrm{v} / \mathrm{v})$ & 1.0 & $87 \pm 3$ & opaque \\
\hline $8 b$ & cis & $\mathrm{DMSO} / \mathrm{H}_{2} \mathrm{O}(2: 1, \mathrm{v} / \mathrm{v})$ & - & $-c$ & - \\
\hline $8 e$ & cis & $\mathrm{DMSO} / \mathrm{H}_{2} \mathrm{O}(1: 1, \mathrm{v} / \mathrm{v})$ & 1.0 & $96 \pm 2$ & opaque \\
\hline $8 e$ & cis & $\mathrm{DMSO} / \mathrm{H}_{2} \mathrm{O}(2: 1, \mathrm{v} / \mathrm{v})$ & 1.0 & $92 \pm 2$ & translucent \\
\hline
\end{tabular}

aGelling at $T=8{ }^{\circ} \mathrm{C}$ (refrigerator). ${ }^{\mathrm{b}}$ Tube inversion test. ${ }^{\mathrm{c}}$ Soft gel: dropping-ball method failed.

In addition, 4-methoxycarbonyl-substituted ditriazole $\mathbf{8 b}$ also formed a gel, which was, however, too soft for the dropping ball method to be performed correctly. Therein, the ball dropped down immediately, and changing the DMSO/water ratio did not improve this result. In any case, the results obtained using $8 \mathbf{a}$ and $\mathbf{8 e}$ point at the fact that the presence of either the phenyl groups or the bromine atoms are not strictly necessary for gelation, although both might contribute to an overall stabilization of the supramolecular aggregation.

Optical micrographs of the xerogels formed from compounds 7f, 8f, 10, 12, and 14 were obtained by SEM (Figure 2). Analyses of these images revealed typically fibrous networks for all except 10. Compound 7f (trans) showed a dense, thin, short, and interlaced/tangled fiber network. The corresponding $\alpha$-anomer $\mathbf{8 f}$ (cis) exhibited an irregular, porous, and dense structure having thin and short fibers. The xerogel of compound 12 showed long, thin, and relatively straight fibers, with lack of torsion, as well as regularity of the network. Its cis stereoisomer 14 showed a fibrous network, but of much shorter length. However, the gel of compound $\mathbf{1 0}$ showed a different morphology, with short and planar films or scales. This could be due to the high proportion of water in the gel and/or the presence of the three free hydroxy groups in its structure, changing its intermolecular self-assembly behavior.

Various efforts were made to crystallize the obtained compounds; however, only $\mathbf{1 2}$ led to single crystals suitable for X-ray crystallography. Its analysis (Figure 3) not only confirmed the structure, but in addition showed a well-organized crystal packing (Figure 4) where the alternate disposition of the molecules displayed a parallelism between the $p$-bromophenyl 

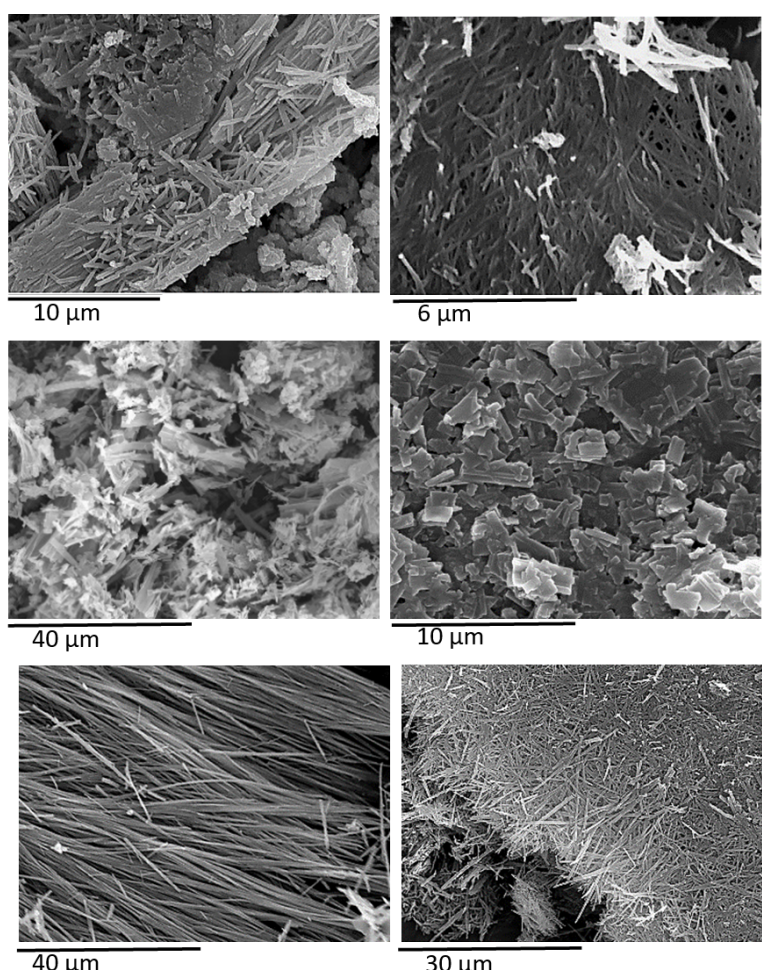

$40 \mu \mathrm{m}$

$30 \mu \mathrm{m}$

Figure 2: SEM images of the xerogels of compounds $7 f$ (DMSO, top left), 8f (DMSO/ $\mathrm{H}_{2} \mathrm{O}, 3: 1, \mathrm{v} / \mathrm{v}$, top right), $10\left(\mathrm{DMSO} / \mathrm{H}_{2} \mathrm{O}, 1: 1, \mathrm{v} / \mathrm{v}\right.$, middle left), 10 (DMSO/ $\mathrm{H}_{2} \mathrm{O}, 1: 2, \mathrm{v} / \mathrm{v}$, middle right), 12 (DMSO, bottom left), and 14 (DMSO/ $\mathrm{H}_{2} \mathrm{O}, 9: 1, \mathrm{v} / \mathrm{v}$, bottom right).

groups as well as between the triazole rings, and therefore the presence of multiple intermolecular $\pi-\pi$ stacking and $\pi$-bromine [19] interactions. This compound precipitated in the presence of any amount of water and gelled only in DMSO at a low temperature.

Compound 10 produced pseudo-crystals in DMSO/ $\mathrm{H}_{2} \mathrm{O}(1: 1$, $\mathrm{v} / \mathrm{v}$ ) and its X-ray analysis was not accurate enough to resolve its structure. However, its crystal packing (Figure 5) deserves discussion. As with compound 12, this packing revealed a number of $\pi$-bromine interactions [19], together with a high degree of $\pi-\pi$ stacking interactions between the aromatic rings, and also that they occured between specific phenyltriazoles. Specifically, these interactions formed between the phenyltriazole moieties in position 1 of a monosaccharide (A) and the phenyltriazole functions in position 1 of its vicinal monosaccharide $(B$, Figure 5, red lines). Similarly, the phenyltriazole substituents in position 2 of this monosaccharide (B) interacted with a corresponding phenyltriazole in position 2 of the vicinal monosaccharide (C, Figure 5, green lines). In addition, it is worth mentioning the presence of a number of DMSO solvate molecules in the crystal packing next to the hydroxymethyl group in position 6 in the $g g$ rotamer, likely linked through hydrogen bonds.

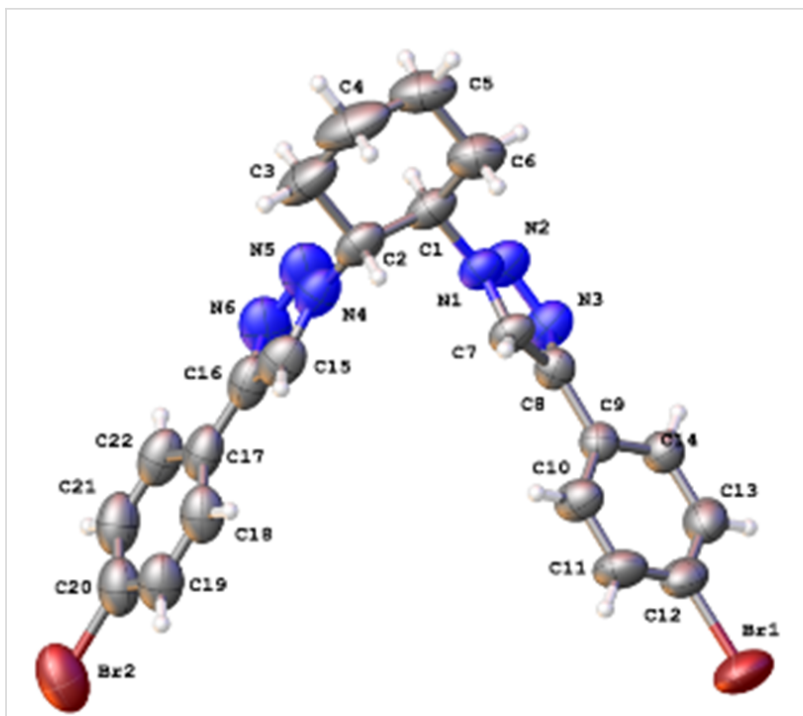

Figure 3: ORTEP representation of the molecular structure of compound 12 (trans configuration) obtained from X-ray diffraction data.

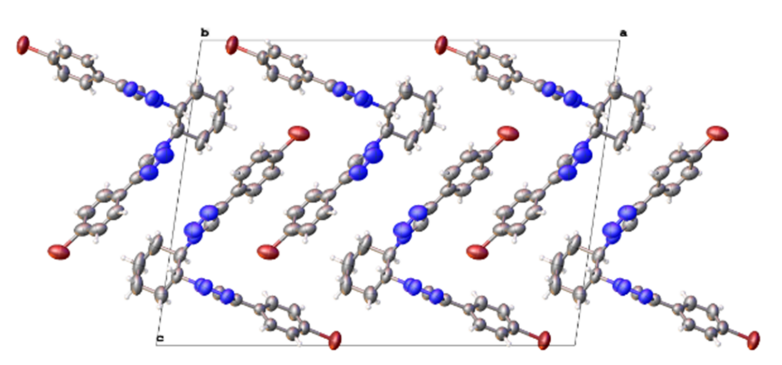

Figure 4: Crystal packing of compound 12 (trans configuration) in DMSO.

Electronic circular dichroism (ECD) is a powerful technique to study supramolecular systems [20,21], since many interactions responsible for the presence of CD Cotton effects occur through space, such as the well-known ECD exciton chirality method [22-24].

ECD of compound $\mathbf{1 0}$ in a DMSO/ $\mathrm{H}_{2} \mathrm{O}(1: 2, \mathrm{v} / \mathrm{v})$ solution and in gel form were successfully measured (Figure 6). ECD of the solution exhibited negative first/positive second exciton Cotton effects at $262(\Delta \varepsilon=-8.6)$ and $242 \mathrm{~nm}(\Delta \varepsilon=+3.3)$, respectively (Figure 6, in black), identical to those obtained for this compound in $\mathrm{CH}_{3} \mathrm{CN}$ [15], although of lower intensity. On the other hand, the ECD spectrum of the gel instead exhibited a normal Cotton effect at $253 \mathrm{~nm}(\Delta \varepsilon=-3.8)$, which, at the same time, was the wavelength of its absorption maximum (Figure 6, in blue). The striking absence of exciton Cotton effects is in complete agreement with the high degree of parallelism between the chromophores, as observed in the crystal packing (Figure 5). Two chromophores can only be coupled under an exciton inter- 


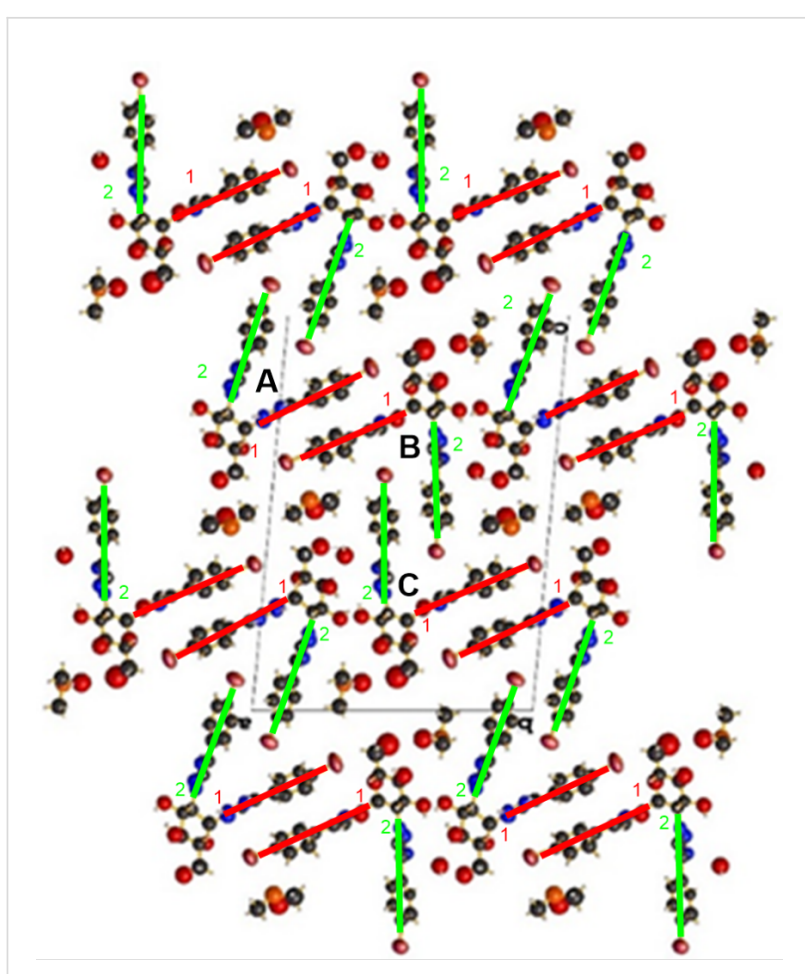

Figure 5: Crystal packing of $\mathbf{1 0}$ (cis configuration) in $\mathrm{DMSO} / \mathrm{H}_{2} \mathrm{O}(1: 1$, $\mathrm{v} / \mathrm{v}$ ). Colored lines: $\Pi-\Pi$ stacking interactions between phenyltriazoles in positions 1 (red lines) and 2 (green lines).

action if the angle between the ${ }^{1} \mathrm{~L}_{\mathrm{a}}$ transitions is different from $0^{\circ}$ or $180^{\circ}$, since this interaction is governed by an equation with a vectorial product. The lack of exciton pairwise interactions between the two chromophores in positions 1 and 2 of each molecule could be due to the intercalation of a third chromophore between the two former in a parallel disposition to one of them (see Figure 5).

\section{Conclusion}

In summary, the capacity of di-1,4-disubstituted 1,2,3-triazoles to form gels was studied taking the dependence on the trans/cis configuration of the molecules into account. The results clearly show that compounds having the cis configuration are more prone to forming thermoreversible gels than those with the trans configuration. In fact, compound $\mathbf{1 0}$, with an $\alpha$-anomeric configuration (cis), showed the lowest gelation concentration at room temperature ( $\mathrm{G} 0.5 \% \mathrm{w} / \mathrm{w}$ ) in $\mathrm{DMSO} / \mathrm{H}_{2} \mathrm{O}, 1: 2$, v/v.

The crystal structures obtained for either the cis or trans configuration through X-ray diffraction studies can be considered good approximations to the supramolecular structure of aryltriazoles in gels. Thus, these compounds showed a high degree of parallelism between the phenyltriazolyl rings, therefore revealing the presence of $\pi-\pi$ stacking and $\pi$-bromine interactions. In addition, compound $\mathbf{1 0}(\mathrm{cis})$, with free hydroxy groups,

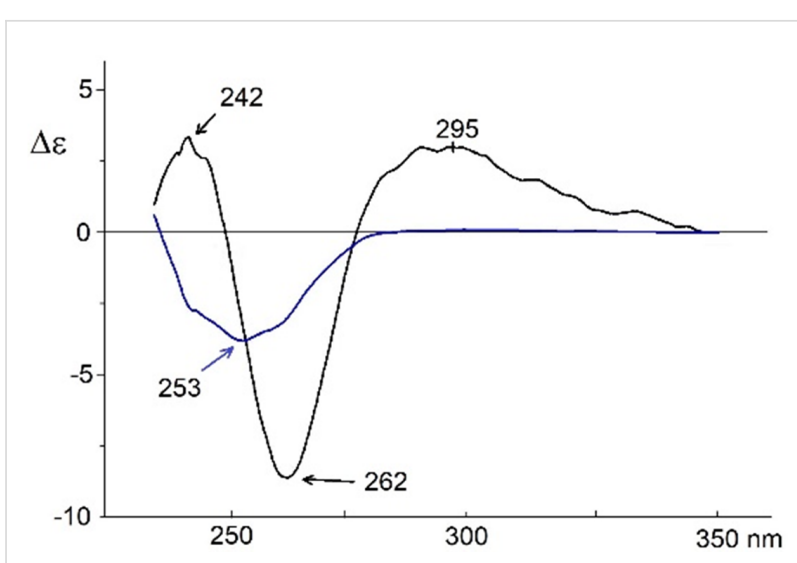

Figure 6: CD spectra of compound 10 (cis) in $\mathrm{DMSO} / \mathrm{H}_{2} \mathrm{O}(1: 2, \mathrm{v} / \mathrm{v})$ in solution (in black) and as gel (in blue).

formed hydrogen bonds between the hydroxymethyl groups in position 6 and DMSO molecules while in a $g g$ rotamer conformation. The different types of EDC spectra obtained for compound $\mathbf{1 0}$ in solution (exciton) and in gel (non-exciton), using $\mathrm{DMSO} / \mathrm{H}_{2} \mathrm{O}, 1: 2, \mathrm{v} / \mathrm{v}$, is in total agreement with the supramolecular structure of the crystal packing of this compound (Figure 5).

\section{Experimental \\ General information}

${ }^{1} \mathrm{H}$ NMR spectra were recorded at 500 and $600 \mathrm{MHz}$, and ${ }^{13} \mathrm{C}$ NMR spectra at 100, 125, and $150 \mathrm{MHz}$ (VTU $300.0 \mathrm{~K}$ ). Chemical shifts are reported in ppm. The residual solvent peak was used as an internal reference. HRMS was performed by HRTOFMS in positive mode (ES+). For analytical and preparative thin-layer chromatography, silica gel ready-foils and glassbacked plates $(1 \mathrm{~mm})$ were used, respectively. These were visualized using UV light at $\lambda=254 \mathrm{~nm}$ and/or developed by spraying with $\mathrm{AcOH} / \mathrm{H}_{2} \mathrm{O} / \mathrm{H}_{2} \mathrm{SO}_{4}(20: 4: 1, \mathrm{v} / \mathrm{v} / \mathrm{v})$ and heating to $150{ }^{\circ} \mathrm{C}$. Column chromatography was performed using silica gel (0.015-0.04 mm) and $n$-hexane/EtOAc solvent systems. All reagents were obtained from commercial sources and used without further purification. Solvents were dried and distilled before use. ECD was recorded in the range of 200-400 $\mathrm{nm}$ at room temperature by using $10 \mathrm{~mm}$ quartz cells. SEM images were taken by a TEM, JEOL JEM 1010 belonging to the Electronic Microscopy Service (SEGAI) of the University of La Laguna, Spain.

Compounds 7f, 8f, 9, 10, 11, and 12 were prepared and characterized as described in reference [15].

\section{Gelation test}

Melting points were measured using the dropping ball method. For that, a stainless steel ball of ca. $3 \mathrm{~mm}$ diameter $(m=$ 
$130.2 \mathrm{mg}$ ) was placed on the gel in a tube with a diameter of $1 \mathrm{~cm}$. This was placed inside an oil bath together with a thermometer, and the temperature of the gel melting was recorded.

\section{Synthesis and characterization}

1,2-Bis[4-(4-bromophenyl)-1H-1,2,3-triazol-1-yl]-1,2dideoxy- $\alpha$-D-glucopyranoside (10): This compound was prepared as described before [15]. $\mathrm{UV}\left(\mathrm{CH}_{3} \mathrm{CN}\right) \lambda_{\max }(\varepsilon) 253 \mathrm{~nm}$ (48000); $\mathrm{CD}\left(\mathrm{CH}_{3} \mathrm{CN}\right) \lambda_{\text {ext }}(\Delta \varepsilon) 242(+8.9), 261(-26.5)$, $299 \mathrm{~nm}(+1.1)$; CD (DMSO: $\left.\mathrm{H}_{2} \mathrm{O}, 1: 2, \mathrm{v} / \mathrm{v}\right) \lambda_{\mathrm{ext}}(\Delta \varepsilon) 242(+3.3)$ $262(-8.6), 295 \mathrm{~nm}(+3.0)$; CD of gel (DMSO: $\left.\mathrm{H}_{2} \mathrm{O}, 1: 2, \mathrm{v} / \mathrm{v}\right)$ $\lambda_{\text {ext }}(\Delta \varepsilon) 253 \mathrm{~nm}(-3.8)$.

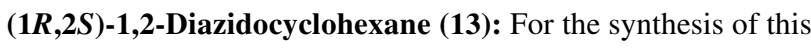
compound, $(1 R, 2 S)$-1,2-diaminocyclohexane and $\mathrm{TfN}_{3}$ were required. (a) The triflyl azide was prepared as follows: Sodium azide (922 mg, $14.2 \mathrm{mmol}$ ), dissolved in pyridine (15 mL), was cooled to $0{ }^{\circ} \mathrm{C}$ under vigorous stirring. Then, triflic anhydride $(1.7 \mathrm{~mL}, 10.1 \mathrm{mmol})$ was added dropwise, and the reaction mixture was left for $2 \mathrm{~h}$ at $0{ }^{\circ} \mathrm{C}$ under vigorous stirring. During that time, a small amount of precipitate appeared, which was removed by filtration. The yellow solution was directly used in the next step. (b) To a solution of $(1 R, 2 S)$-1,2-diaminocyclohexane $(0.42 \mathrm{~mL}, 3.5 \mathrm{mmol})$ in $5 \mathrm{~mL}$ of pyridine, $\mathrm{CuSO}_{4} \cdot 5 \mathrm{H}_{2} \mathrm{O}$ (15 mg, $0.06 \mathrm{mmol}$ ) was added while stirring. The mixture was cooled in an ice bath and the above-prepared solution of triflyl azide added dropwise. The resulting green reaction mixture was allowed to warm to room temperature and left for $20 \mathrm{~h}$. The reaction mixture was diluted with $\mathrm{CH}_{2} \mathrm{Cl}_{2}(100 \mathrm{~mL})$ and extracted using diluted $\mathrm{HCl}$ until the $\mathrm{pH}$ value was acidic $(4 \times 20 \mathrm{~mL})$. The organic phase was washed with $\mathrm{NaHCO}_{3}$ $(2 \times 10 \mathrm{~mL})$ and dried with sodium sulfate. Then, the organic solvent was removed at reduced pressure, keeping the temperature below $30{ }^{\circ} \mathrm{C}$. The residue ( $\left.437 \mathrm{mg}, 75 \%\right)$ showed spectroscopic data according to the literature [25]. ${ }^{1} \mathrm{H}$ NMR $(600 \mathrm{MHz}$, $\left.\mathrm{CDCl}_{3}\right) \delta 3.62(\mathrm{~d}, J=8.4 \mathrm{~Hz}, 2 \mathrm{H}), 1.85(\mathrm{~m}, 2 \mathrm{H}), 1.64(\mathrm{~m}, 4 \mathrm{H})$, $1.38 \mathrm{ppm}(\mathrm{m}, 2 \mathrm{H}) ;{ }^{13} \mathrm{C} \mathrm{NMR}\left(150 \mathrm{MHz}, \mathrm{CDCl}_{3}\right) \delta 61.4,27.3$, $21.6 \mathrm{ppm}$.

$(1 R, 2 S)-1,2-B i s(4-(4-b r o m o p h e n y l)-1 H-1,2,3-t r i a z o l-1-$ yl)cyclohexane (14): To a solution of $(1 R, 2 S)$-1,2-diazidocyclohexane (13, $363 \mathrm{mg}, 2.19 \mathrm{mmol})$ in $\mathrm{H}_{2} \mathrm{O}(22 \mathrm{~mL}, 22 \mathrm{mmol})$, 1-bromo-4-ethynylbenzene ( $913 \mathrm{mg}, 5.04 \mathrm{mmol}$ ), $\mathrm{CuSO}_{4} \cdot 5 \mathrm{H}_{2} \mathrm{O}$ (40 mg, $0.16 \mathrm{mmol}$ ) as a $1 \mathrm{M}$ aq. solution, and sodium ascorbate $(152 \mathrm{mg} 0.77 \mathrm{mmol})$ as a $1 \mathrm{M}$ aq. solution, were added. The reaction mixture was heated to $70{ }^{\circ} \mathrm{C}$ for $48 \mathrm{~h}$. Then, the organic layer was extracted with EtOAc $(3 \times 100 \mathrm{~mL})$ and the solvent removed at reduced pressure. The residue was chromatographed on silica gel using $n$-hexane/EtOAc to give compound 14 (782 mg, 68\% yield). $R_{\mathrm{f}} 0.35$ ( $n$-hexane/EtOAc, $1: 1$, $\mathrm{v} / \mathrm{v}) ; \mathrm{mp} 286-288^{\circ} \mathrm{C} ;{ }^{1} \mathrm{H}$ NMR $\left(500 \mathrm{MHz}, \mathrm{CDCl}_{3}\right) \delta$ 7.46-7.42 (m, 8H), 7.18 (s, 2H), $5.18(\mathrm{~m}, 2 \mathrm{H}), 2.57(\mathrm{~m}, 2 \mathrm{H}), 2.34(\mathrm{~m}, 2 \mathrm{H})$, 2.19 (m, 2H), $2.77 \mathrm{ppm}(\mathrm{m}, 2 \mathrm{H}) ;{ }^{13} \mathrm{C} \mathrm{NMR}\left(150 \mathrm{MHz}, \mathrm{CDCl}_{3}\right)$ $\delta 146.2,131.9,128.9,127.1,122.2,119.9,60.8,28.0,22.3$ ppm; HRESIMS $(\mathrm{m} / \mathrm{z})$ : $[\mathrm{M}+\mathrm{Na}]^{+}$calcd for $\mathrm{C}_{22} \mathrm{H}_{20}{ }^{79} \mathrm{Br}_{2} \mathrm{~N}_{6} \mathrm{Na}$, 549.0014; found, 549.0023; $[\mathrm{M}+\mathrm{Na}]^{+}$calcd for $\mathrm{C}_{22} \mathrm{H}_{20}{ }^{79} \mathrm{Br}^{81} \mathrm{BrN}_{6} \mathrm{Na}$, 550.9993; found, 551.0006; [M + Na $]^{+}$ calcd for $\mathrm{C}_{22} \mathrm{H}_{20}{ }^{81} \mathrm{Br}_{2} \mathrm{~N}_{6} \mathrm{Na}$, 552.9973; found, 552.9977; anal. calcd for $\mathrm{C}_{22} \mathrm{H}_{20} \mathrm{Br}_{2} \mathrm{~N}_{6}, \mathrm{C}, 50.02 ; \mathrm{H}, 3.82 ; \mathrm{N}, 15.91 \%$; found, C, 49.67; H, 3.90; N, 16.22\%.

\section{Supporting Information}

\section{Supporting Information File 1}

An SEM image collection of the xerogels and X-ray data for compound $\mathbf{1 2}$.

[https://www.beilstein-journals.org/bjoc/content/ supplementary/1860-5397-15-282-S1.pdf]

\section{Acknowledgements}

This work was supported by the Spanish MINECO and cofinanced by the European Regional Development Fund (ERDF) CTQ2014-56362-C2-1-P. The authors thank Prof. David Díaz (University of Regensburg) for his help and useful suggestions.

\section{ORCID ${ }^{\circledR}$ iDs}

Giada Caniglia - https://orcid.org/0000-0002-8116-0131 Rosa L. Dorta - https://orcid.org/0000-0002-4565-0301 Andrea Favero - https://orcid.org/0000-0001-5119-2071 Javier González-Platas - https://orcid.org/0000-0003-3339-2998 Jesús T. Vázquez - https://orcid.org/0000-0002-3622-3148

\section{References}

1. Babu, S. S.; Praveen, V. K.; Ajayaghosh, A. Chem. Rev. 2014, 114, 1973-2129. doi:10.1021/cr400195e

2. Cornwell, D. J.; Smith, D. K. Mater. Horiz. 2015, 2, 279-293. doi:10.1039/c4mh00245h

3. Hirst, A. R.; Escuder, B.; Miravet, J. F.; Smith, D. K. Angew. Chem., Int. Ed. 2008, 47, 8002-8018. doi:10.1002/anie.200800022

4. Lallana, E.; Fernández-Trillo, F.; Sousa-Herves, A.; Riguera, R.; Fernández-Megía, E. Pharm. Res. 2012, 29, 902-921. doi:10.1007/s11095-012-0683-y

5. Thirumurugan, P.; Matosiuk, D.; Jozwiak, K. Chem. Rev. 2013, 113, 4905-4979. doi:10.1021/cr200409f

6. Chai, Q.; Jiao, Y.; Yu, X. Gels 2017, 3, No. 6. doi:10.3390/gels3010006

7. Mangunuru, H. P. R.; Yerabolu, J. R.; Liu, D.; Wang, G. Tetrahedron Lett. 2015, 56, 82-85. doi:10.1016/j.tetlet.2014.11.013

8. Wang, G.; Chen, A.; Mangunuru, H. P. R.; Yerabolu, J. R. RSC Adv. 2017, 7, 40887-40895. doi:10.1039/c7ra06228a

9. Okafor, I. S.; Wang, G. Carbohydr. Res. 2017, 451, 81-94. doi:10.1016/j.carres.2017.09.008

10. Tautz, M.; Torras, J.; Grijalvo, S.; Eritja, R.; Saldías, C.; Alemán, C.; Díaz, D. D. RSC Adv. 2019, 9, 20841-20851. doi:10.1039/c9ra03316e 
11. Zhang, H.-Z.; Wei, J.-J.; Kumar, K. V.; Rasheed, S.; Zhou, C.-H.

Med. Chem. Res. 2015, 24, 182-196. doi:10.1007/s00044-014-1123-9

12. Dedola, S.; Hughes, D. L.; Nepogodiev, S. A.; Rejzek, M.; Field, R. A. Carbohydr. Res. 2010, 345, 1123-1134.

doi:10.1016/j.carres.2010.03.041

13. Bokor, É.; Docsa, T.; Gergely, P.; Somsák, L. Bioorg. Med. Chem.

2010, 18, 1171-1180. doi:10.1016/j.bmc.2009.12.043

14. Goyard, D.; Docsa, T.; Gergely, P.; Praly, J.-P.; Vidal, S.

Carbohydr. Res. 2015, 402, 245-251.

doi:10.1016/j.carres.2014.10.009

15. Tejera, S.; Dorta, R. L.; Vázquez, J. T. Tetrahedron: Asymmetry 2016, 27, 896-909. doi:10.1016/j.tetasy.2016.07.008

16. Kolb, H. C.; Finn, M. G.; Sharpless, K. B. Angew. Chem., Int. Ed. 2001, 40, 2004-2021.

doi:10.1002/1521-3773(20010601)40:11<2004::aid-anie2004>3.0.co;25

17. Rostovtsev, V. V.; Green, L. G.; Fokin, V. V.; Sharpless, K. B. Angew. Chem., Int. Ed. 2002, 41, 2596-2599. doi:10.1002/1521-3773(20020715)41:14<2596::aid-anie2596>3.0.co;24

18. Tornøe, C. W.; Christensen, C.; Meldal, M. J. Org. Chem. 2002, 67, 3057-3064. doi:10.1021/j0011148j

19. Cavallo, G.; Metrangolo, P.; Milani, R.; Pilati, T.; Priimagi, A.; Resnati, G.; Terraneo, G. Chem. Rev. 2016, 116, 2478-2601. doi:10.1021/acs.chemrev.5b00484

20. Gottarelli, G.; Lena, S.; Masiero, S.; Pieraccini, S.; Spada, G. P. Chirality 2008, 20, 471-485. doi:10.1002/chir.20459

21. Pescitelli, G.; Di Bari, L.; Berova, N. Chem. Soc. Rev. 2014, 43, 5211-5233. doi:10.1039/c4cs00104d

22. Circular Dichroism: Principles and Applications, 2nd ed.; Berova, N.; Nakanishi, K.; Woody, R. W., Eds.; Wiley-VCH: Weinheim, 2000.

23. Lightner, D. A.; Gurst, J. E. Organic Conformational Analysis and Stereochemistry from Circular Dichroism Spectroscopy; Wiley-VCH: Weinheim, 2000.

24. Pescitelli, G.; Di Bari, L.; Berova, N. Chem. Soc. Rev. 2011, 40, 4603-4625. doi:10.1039/c1cs15036g

25. Magnus, P.; Lacour, J.; Evans, P. A.; Roe, M. B.; Hulme, C. J. Am. Chem. Soc. 1996, 118, 3406-3418. doi:10.1021/ja953906r

\section{License and Terms}

This is an Open Access article under the terms of the Creative Commons Attribution License (http://creativecommons.org/licenses/by/4.0). Please note that the reuse, redistribution and reproduction in particular requires that the authors and source are credited.

The license is subject to the Beilstein Journal of Organic Chemistry terms and conditions: (https://www.beilstein-journals.org/bjoc)

The definitive version of this article is the electronic one which can be found at: doi:10.3762/bjoc. 15.282 